\title{
Article \\ Patient-Derived Human Basal and Cutaneous Squamous Cell Carcinoma Tissues Display Apoptosis and Immunomodulation following Gas Plasma Exposure with a Certified Argon Jet
}

\author{
Fariba Saadati ${ }^{1}$, Juliane Moritz ${ }^{1}$, Julia Berner ${ }^{1,2}$, Eric Freund ${ }^{1,3} \mathbb{D}^{\mathbb{D}}$, Lea Miebach 1,3 $\mathbb{D}$, Iris Helfrich ${ }^{4,5,6,7} \mathbb{D}$, \\ Ingo Stoffels ${ }^{4,5,6}$, Steffen Emmert ${ }^{8}$ and Sander Bekeschus $1, *$ (D)
}

1 ZIK Plasmatis, Leibniz Institute for Plasma Science and Technology (INP), Felix-Hausdorff-Str. 2, 17489 Greifswald, Germany; fariba.saadati@inp-greifswald.de (F.S.); juliane.moritz@inp-greifswald.de (J.M.); julia.berner@inp-greifswald.de (J.B.); eric.freund@inp-greifswald.de (E.F.); lea.miebach@inp-greifswald.de (L.M.)

2 Department of Oral and Maxillofacial Surgery, Plastic Surgery, Greifswald University Medical Center, Ferdinand-Sauerbruch-Str., 17475 Greifswald, Germany

3 Department of General, Visceral, Thoracic and Vascular Surgery, Greifswald University Medical Center, Ferdinand-Sauerbruch-Str., 17475 Greifswald, Germany

4 Departments of Dermato-Oncology, Essen/Duisburg University Medical Center, Hufelandstr. 55, 45147 Essen, Germany; iris.helfrich@uk-essen.de (I.H.); ingo.stoffels@uk-essen.de (I.S.)

check for updates

Citation: Saadati, F.; Moritz, J.; Berner, J.; Freund, E.; Miebach, L.; Helfrich, I.; Stoffels, I.; Emmert, S.; Bekeschus, S. Patient-Derived Human Basal and Cutaneous Squamous Cell Carcinoma Tissues Display Apoptosis and Immunomodulation following Gas Plasma Exposure with a Certified Argon Jet. Int. J. Mol. Sci. 2021, 22, 11446. https://doi.org/10.3390/ ijms222111446

Academic Editors: Akikazu Sakudo and Yoshihito Yagyu

Received: 4 September 2021 Accepted: 21 October 2021 Published: 23 October 2021

Publisher's Note: MDPI stays neutral with regard to jurisdictional claims in published maps and institutional affiliations.

Copyright: (c) 2021 by the authors. Licensee MDPI, Basel, Switzerland. This article is an open access article distributed under the terms and conditions of the Creative Commons Attribution (CC BY) license (https:/ / creativecommons.org/licenses/by/ $4.0 /)$.
5 West-German Cancer Center, Essen/Duisburg University Medical Center, Hufelandstr. 55, 45147 Essen, Germany

6 German Consortium for Translational Cancer Research, Essen/Duisburg University Medical Center, Hufelandstr. 55, 45147 Essen, Germany

7 Department of Dermatology and Allergology of the Ludwig Maximilian University Hospital Munich, 80337 Munich, Germany

8 Clinic for Dermatology and Venerology, Rostock University Medical Center, Strempelstr. 13, 18057 Rostock, Germany; steffen.emmert@med.uni-rostock.de

* Correspondence: sander.bekeschus@inp-greifswald.de

Abstract: Reactive oxygen species (ROS) have been subject of increasing interest in the pathophysiology and therapy of cancers in recent years. In skin cancer, ROS are involved in UV-induced tumorigenesis and its targeted treatment via, e.g., photodynamic therapy. Another recent technology for topical ROS generation is cold physical plasma, a partially ionized gas expelling dozens of reactive species onto its treatment target. Gas plasma technology is accredited for its wound-healing abilities in Europe, and current clinical evidence suggests that it may have beneficial effects against actinic keratosis. Since the concept of hormesis dictates that low ROS levels perform signaling functions, while high ROS levels cause damage, we investigated herein the antitumor activity of gas plasma in non-melanoma skin cancer. In vitro, gas plasma exposure diminished the metabolic activity, preferentially in squamous cell carcinoma cell (SCC) lines compared to non-malignant HaCaT cells. In patient-derived basal cell carcinoma (BCC) and SCC samples treated with gas plasma ex vivo, increased apoptosis was found in both cancer types. Moreover, the immunomodulatory actions of gas plasma treatment were found affecting, e.g., the expression of CD86 and the number of regulatory T-cells. The supernatants of these ex vivo cultured tumors were quantitatively screened for cytokines, chemokines, and growth factors, identifying CCL5 and GM-CSF, molecules associated with skin cancer metastasis, to be markedly decreased. These findings suggest gas plasma treatment to be an interesting future technology for non-melanoma skin cancer topical therapy.

Keywords: chemokines; cold physical plasma; cytokines; reactive oxygen species; ROS; skin cancer

\section{Introduction}

Basal cell carcinoma (BCC) and squamous cell carcinoma (SCC) are highly prevalent skin cancers $[1,2]$. SCC is a relatively slow-growing skin cancer that can expand to the 
surrounding tissue and further into the body (metastasis). On the contrary, BCC rarely metastasizes but has invasive and destructive local growth [3]. Changes and diversity in the tumor microenvironment (TME) and the unknown nature of several other factors partially explain the failure of definitive treatment for these diseases in some cases $[4,5]$. Based on recent studies, the tumor microenvironment (TME) plays a significant role in tumor progression, response to treatment, growth, and the acquisition of the metastatic pattern by tumor cells [6]. In addition to all the classic strategies of tumors escaping the immune system responses, e.g., antigen expression reduction, resistance to cell lysis by the immune cells, and the expression and secretion of immune suppressor factors, the tumor also escapes the immune system under TME complexity $[7,8]$. Thus, looking for different treatment methods to target these tumors, especially in cases where resection is impossible, and examining the TME response to treatment is of utmost importance.

In recent decades, cold physical plasma has been used as a powerful tool for inhibiting growth and destroying cancer cells $[9,10]$. Numerous studies have demonstrated the physical plasma's toxicity on different tumor entities, including glioblastoma [11,12] and skin [13,14], breast [15-17], colorectal [18,19], head and neck [20,21], and lung cancer [22,23]. The anticancer mechanism of physical plasma is complex, but it is assumed that the plethora of reactive oxygen species (ROS) generated by the plasma discharge affects cell functions by disrupting the intracellular redox balance and membrane antioxidant enzymes [24]. ROS are relatively short-lived molecules containing oxygen that are chemically active [25]. At supraphysiological concentrations, ROS damage membranes, DNA, mitochondria, and the endoplasmic reticulum, eventually leading to, e.g., apoptosis, necrosis, senescence, or autophagy [26,27]. Moreover, the mechanism of chemotherapy, photodynamic therapy, and radiotherapy are at least partially based on ROS generation and subsequent apoptosis induction [28,29]. Due to tumor cells' strong reliance on physiological homeostasis with ROS, they are prone to perturbations in redox homeostasis and oxidative distress [30]. Importantly, such stress is also considered a central prerequisite in many types of chemotherapy [31].

Many cancers express a strong network of cytokines and chemokines as well as their receptors. For instance, tumor cells stimulate endothelial cells by chemokine and cytokine expression to loosen their contact inhibition for invasion and metastasis to other tissues [32]. In general, the immune system plays a pivotal and influential role in maintaining the body's homeostasis and destroying tumors, in addition to its fundamental role in dealing with external and infectious agents [33]. Tumor cells can manipulate immune cells by, for instance, adapting their metabolic needs to ultimately enhance instead of halt cancer growth [34]. Hence, investigating the TME is of great importance in oncology.

In this study, the toxicity of a clinically certified atmospheric pressure argon plasma jet on skin cancer cells was investigated in vitro, as well as primary patient-derived SCC and BCC tumor samples ex vivo. We found that gas plasma treatment can induce apoptosis in vitro and in vivo and to modulate the inflammatory profiles of the skin tumor biopsies regarding the secretion of chemokines and cytokines as well as the expression of immunerelated surface markers.

\section{Results}

\subsection{Toxicity of Gas Plasma Treatment in Skin Cancer Cells In Vitro}

The toxicity of different doses of plasma irradiation was examined in four cell lines. A resazurin-based assay was used, which is indicative of total metabolic activity (Figure 1a). Two treatment modes were investigated. The first addressed toxicity in cell lines in suspension, while the second was performed in the cell lines that were allowed to adhere before treatment. An exposure time-dependent decline of metabolic activity was found in the former approach (Figure 1b). Based on these data and the calculated inhibitory concentration $25\left(\mathrm{IC}_{25}\right)$, non-malignant $\mathrm{HaCaT}$ keratinocytes were less prone to gas plasma-induced metabolic activity reduction than the skin cancer cell lines. However, in the latter approach treating cell lines in adherent states, reduced abrogation in metabolic activity was identified 
(Figure 1c). Again, $\mathrm{HaCaT}$ cells' resistance to gas plasma treatment was much greater than those of the other three skin cancer cell types. Due to the fact that the plasma treatment of cells in suspension is less relevant for the therapy of human disease, we focused on the stress responses of adherent plasma-treated cells in the following experiments. Thereby, the previous results were re-iterated by assessing the viability of cells based on caspase 3 and 7 activity and terminal cell death (Figure 1d). A comparable viability reduction was observed after gas plasma exposure across all cell types treated in adherent states (Figure 1e). By analyzing the different cell cycle phase in two tumor cell lines (Figure 1f), changes in the quantitative distribution of the different cell cycle phases were observed in both cell lines, which are indicative of cell cycle arrest (Figure 1g), as confirmed by the calculation of G1/G2 ratios (Figure 1h). The flow cytometry analysis of markers for oxidative stress (Figure 1i) subsequently showed overall treatment time-dependent elevated levels in gas plasma-treated skin cancer cells (Figure 1j), especially for phosphorylated $(\gamma)$ histone 2A.X $(\gamma \mathrm{H} 2 \mathrm{AX})$, suggesting oxidative stress-induced cell death.

a

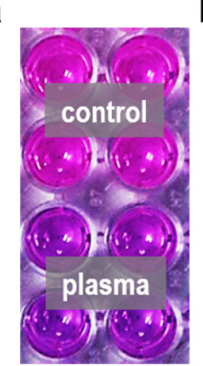

d

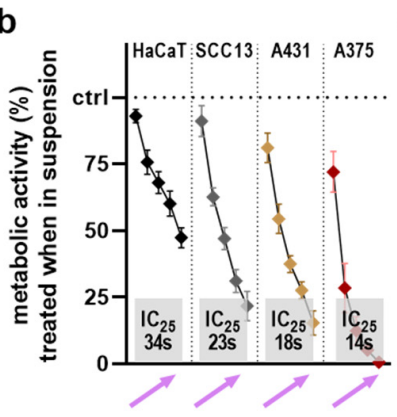

plasma treatment time

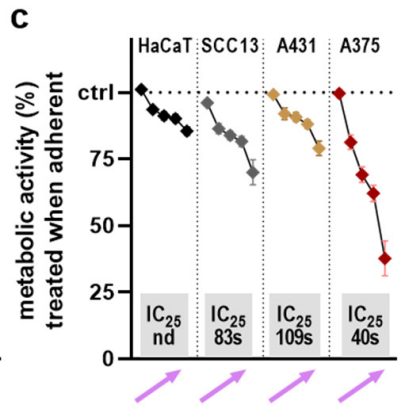

plasma treatment time
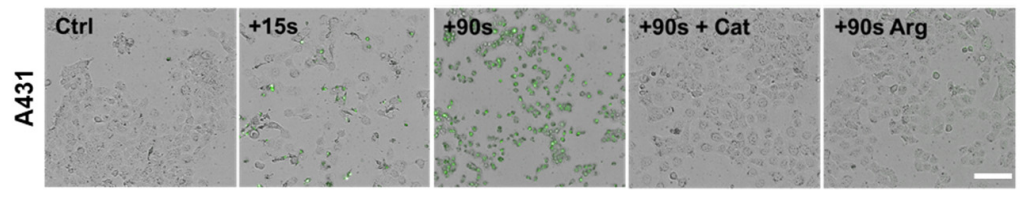

e

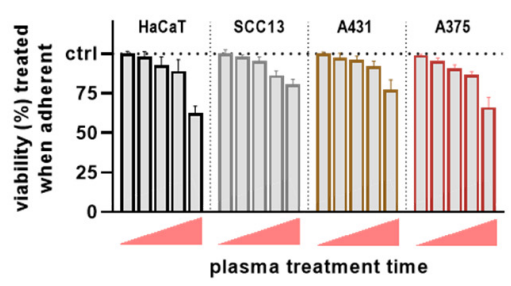

g

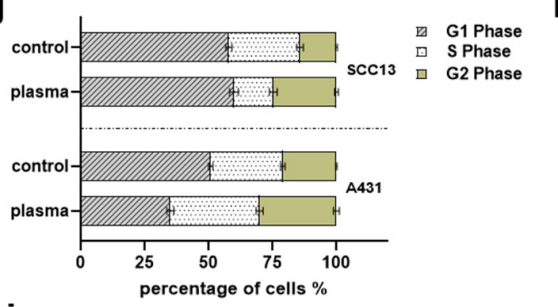

h

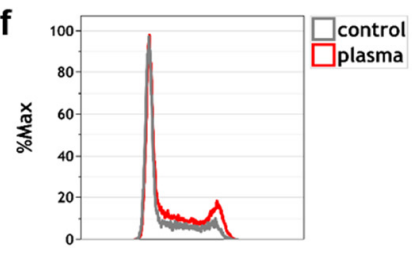

DAPI fluorescence (A)

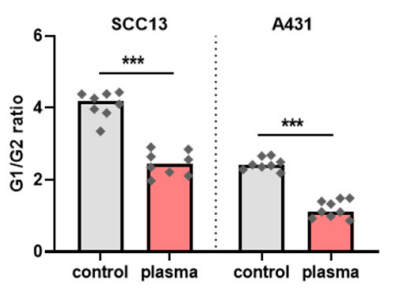

i
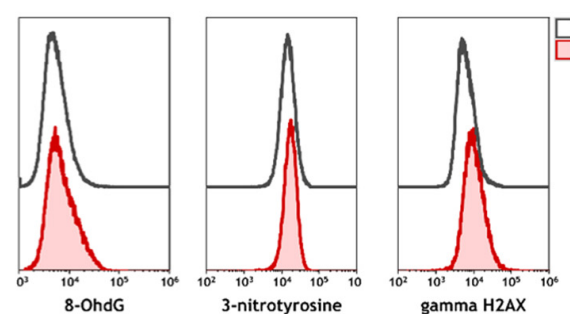

j

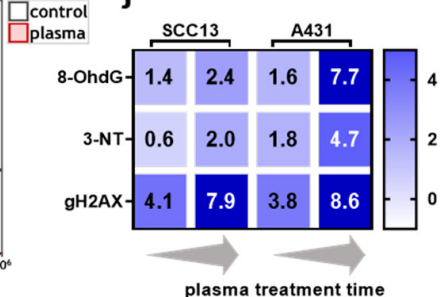

Figure 1. Gas plasma treatment in vitro: (a) image of the metabolic activity assay with higher (control) and lower (bottom) resazurin transformation, respectively; $(\mathbf{b}, \mathbf{c})$ quantitative analysis of gas plasma 
treatment effects in four cell lines exposed in suspension (b) or adherent (c) states, where grey boxes indicate $\mathrm{IC}_{25}$ values; (d) representative brightfield and fluorescence (caspase 3/7, green) overlay images of cells exposed to various conditions, catalase (cat) and argon gas treatment (Arg) served as controls; (e) viability of the four cell lines exposed in adherent state to several plasma treatment times (15 s, $30 \mathrm{~s}, 45 \mathrm{~s}, 60 \mathrm{~s}$ and $90 \mathrm{~s}$ ); (f) representative overlay histogram of the DAPI intensity of control and gas plasma-treated SCC13 samples; (g) quantification of cell cycle phases in fixed and permeabilized DAPI-stained SCC13 and A431 cells after acquisition using flow cytometry and analysis of individual cell cycle phases using mathematical modeling according to the Michael $\mathrm{H}$. Fox algorithm employed in the Kaluza analysis software; (h) G1/G2 ratios calculated from cell cycle data; $(\mathbf{i}, \mathbf{j})$ representative flow cytometry overlay histograms (i) and normalized quantification of three oxidative stress-related markers $(\mathbf{j})$. Data were normalized to control and are displayed as the mean with SEM of three experiments. Statistical analysis was performed using $t$-test with $p<0.001$ $\left.{ }^{* * *}\right)$. Scale bar is $100 \mu \mathrm{m}$.

\subsection{Toxicity and Immunomodulation of Gas Plasma-Treated Skin Cancer Biopsies}

SCC and BCC skin cancer samples were collected from patients to generate biopsies of equal sizes and volumes, followed by gas plasma exposure ex vivo, incubation, and analysis of immunofluorescence tissue analysis and screening for soluble inflammatory markers in the tissue culture supernatants (Figure 2a). To verify that the kINPen used in this study generates reactive oxygen and nitrogen species as collectively described before [34], the stable and long-lived products hydrogen peroxide $\left(\mathrm{H}_{2} \mathrm{O}_{2}\right)$, nitrite $\left(\mathrm{NO}_{2}{ }^{-}\right)$, and nitrate $\left(\mathrm{NO}_{3}{ }^{-}\right)$were quantified in $200 \mu \mathrm{L}$ of phosphate-buffered saline (PBS) after plasma exposure of different treatment times. Argon gas alone (applied at the maximum exposure time used for plasma treatment) served as the control in addition to untreated liquid (i.e., 0s). For all three types of oxidants investigated, their concentration increased in a plasma exposure time-dependent manner (Figure 2b). While the generation of $\mathrm{H}_{2} \mathrm{O}_{2}$ was nearly linear to the plasma treatment time, nitrite and nitrate were quickly generated during short plasma exposure but showed a slower rise for longer treatments. Tissues were sectioned and analyzed for apoptosis and the expression of several markers expressed by cells of the TME (Figure 3a). For BCC, gas plasma exposure significantly increased the percentage of apoptotic cells, while the expression of CD206, a marker of tumorsupportive M2 macrophages, remained unchanged (Figure 3b). Interestingly, a significantly lower expression was found for CD86, a molecule associated with professional antigenpresenting cells, and FOXP3, a transcription factor of regulatory $\mathrm{T}$ cells $\left(\mathrm{T}_{\text {reg }}\right)$. Elevated levels of apoptosis were also found in ex vivo gas plasma-treated patient-derived SCC tissue, while CD206 remained unchanged as in BCC (Figure 3c). Similar to BCC, CD86 was significantly reduced, however, by contrast, the $\mathrm{T}_{\text {reg }}$ numbers remained unchanged. The immunomodulatory effects of gas plasma treatment on primary skin cancer samples were further investigated by quantifying more chemokines, cytokines, and growth factors released into the culture medium during the incubation period. For BCCs, a significant reduction in CCL5, G-CSF, GM-CSF, and IL-1 $\beta$ was observed, while granzyme A and IL-17A release was significantly elevated (Figure 4). In SCC samples, three targets were significantly regulated, namely CCL5 and GM-CSF which were upregulated as observed in the BCC samples, and PDGF-aa being reduced (Figure 5). These results suggest gas plasma treatment to confer toxicity in SCC and BCC and to have an immunomodulatory role. 


\section{a}

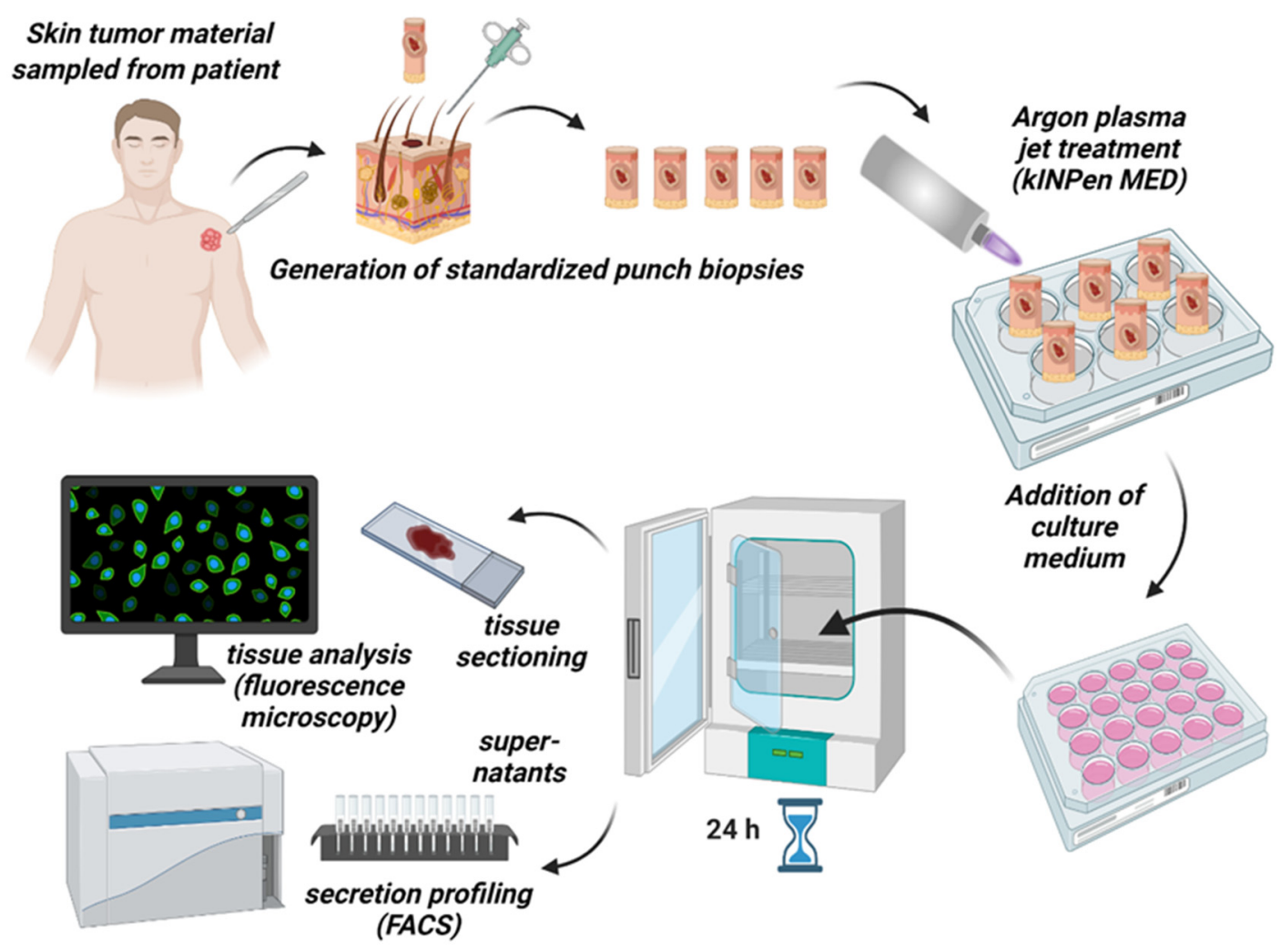

b

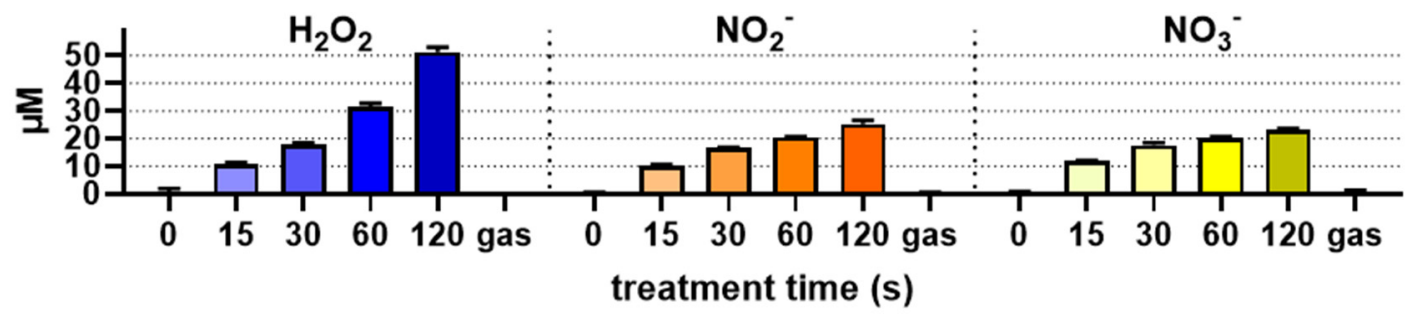

Figure 2. Human tumor tissue sampling and treatment scheme: (a) excised skin tumors were retrieved and used to generate punch biopsies of identical sizes. The punch biopsies were subsequently added to microtiter well plates for standardized gas plasma treatment. Afterward, cell culture medium was added to each well and the samples were incubated for $24 \mathrm{~h}$, before supernatants were collected and tissues were cryo-sectioned and stained. Supernatants were analyzed using multiplex flow cytometry, and cryo-sections were stained with antibodies, followed by quantitative immunofluorescence imaging; (b) quantification of ROS (hydrogen peroxide, $\mathrm{H}_{2} \mathrm{O}_{2}$ ) and $\mathrm{RNS}$ (nitrite, $\mathrm{NO}_{2}{ }^{-}$; nitrate, $\mathrm{NO}_{3}{ }^{-}$) in plasma-treated liquids (200 $\mu \mathrm{L}$ of PBS). Gas refers to $120 \mathrm{~s}$ of exposure of the liquid with argon gas only (i.e., plasma $=$ off). 
a

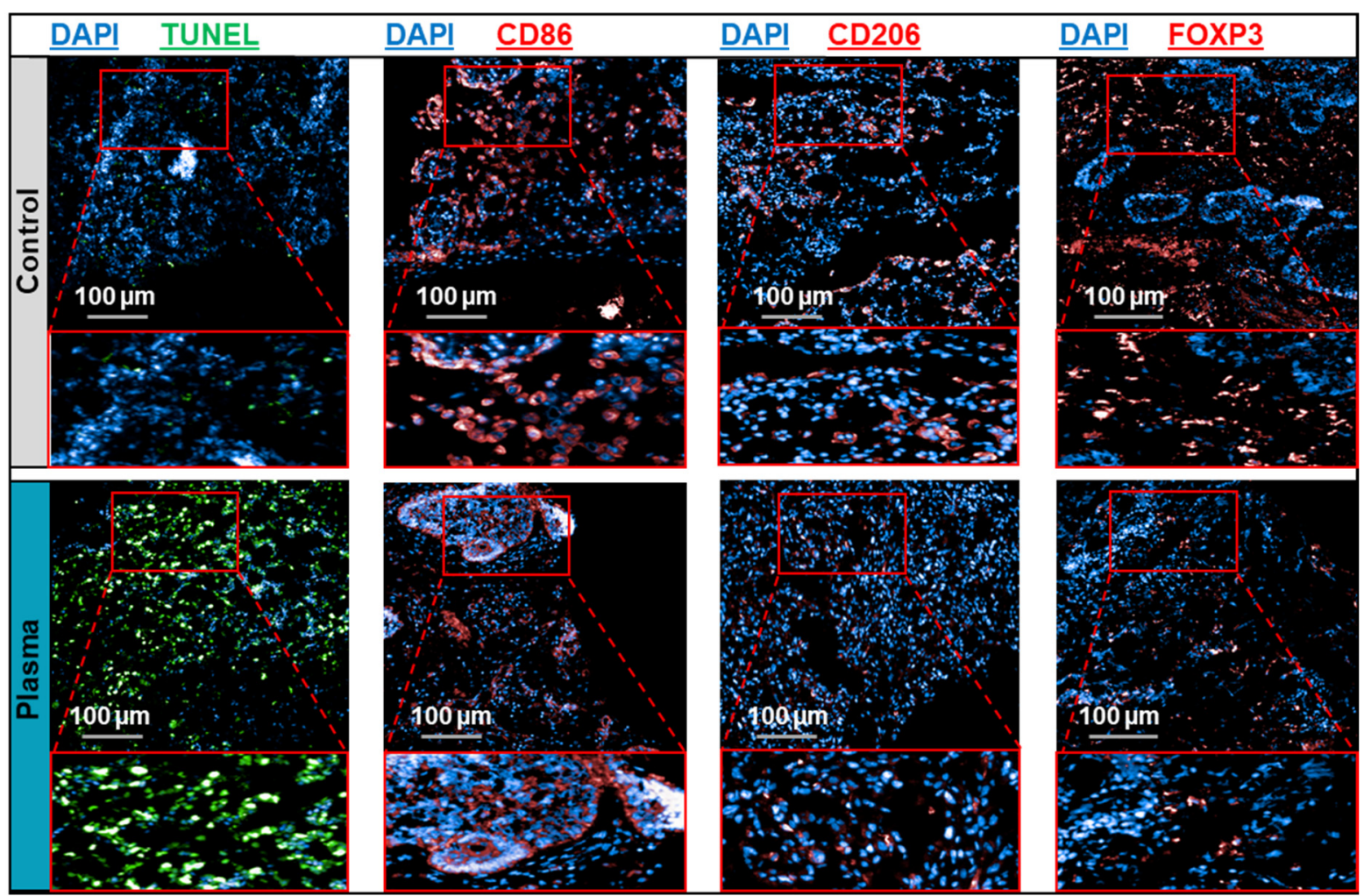

b

BCC
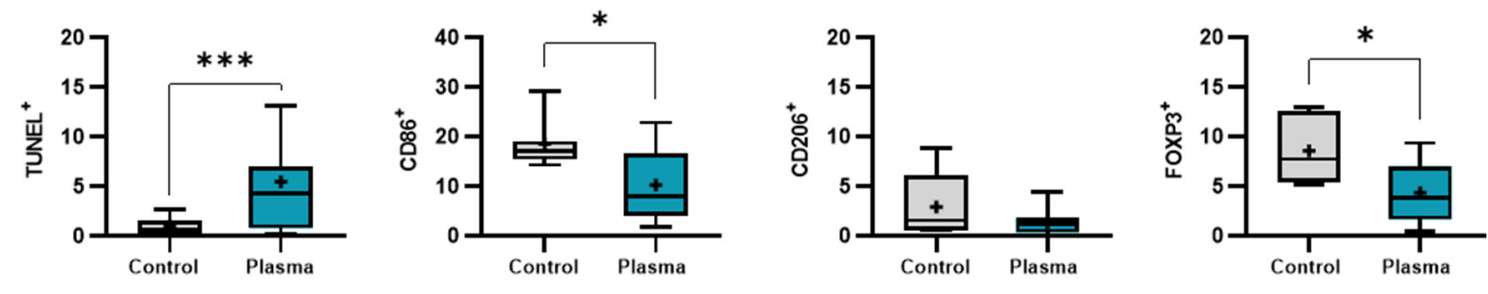

C

ScC
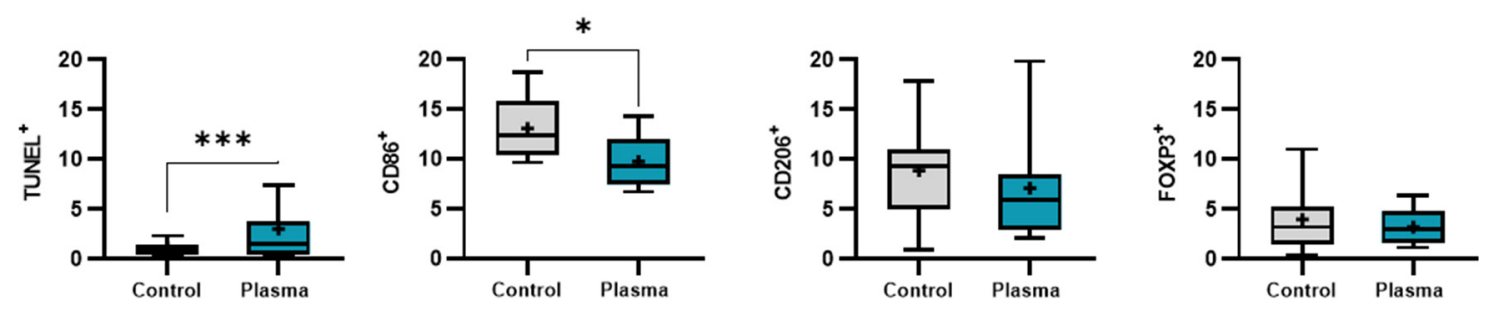

Figure 3. Immunofluorescence analysis: (a) representative immunofluorescence images of DAPI, TUNEL, CD86, CD206, and FOXP3 staining in gas plasma and argon gas (control)-treated BCC tissues; (b) quantitative imaging data for all markers in BCC samples; (c) quantitative imaging data for all markers in SCC samples. Data show boxplots from 6-8 patients, and statistical analysis was performed using $t$-test with $p<0.05\left(^{*}\right)$ and $p<0.001\left(^{* * *}\right)$. Scale bars are $100 \mu \mathrm{m}$. 
BCC chemokines, cytokines, growth factors (pg/ml)
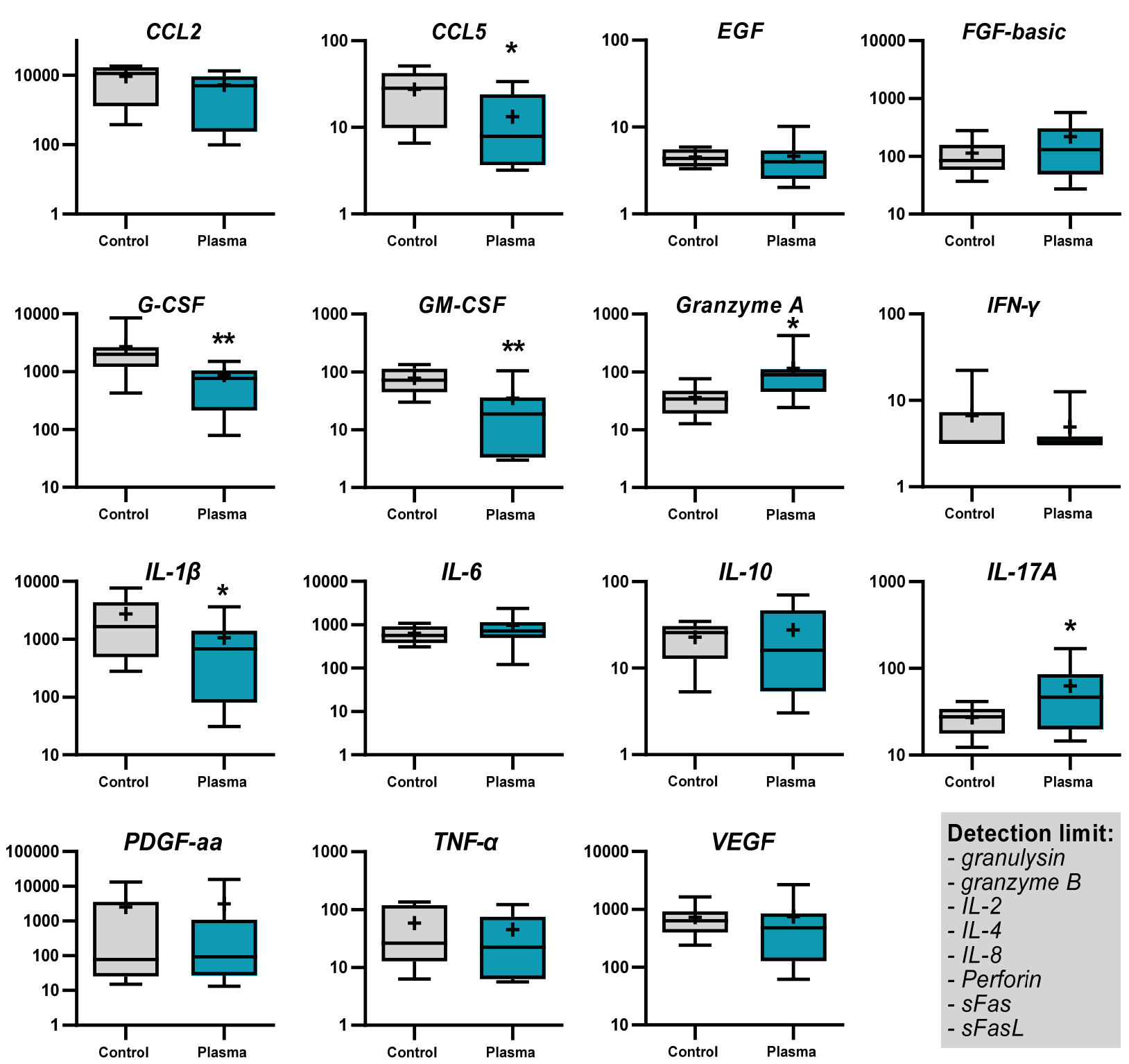

Detection limit:

- granulysin

- granzyme B

- IL-2

$-I L-4$

$-I L-8$

- Perforin

- sFas

- sFasL

Figure 4. Secretion profile of BCCs: quantification of chemokines, cytokines, and growth factors in pg/mL in BCC tissue culture supernatants $24 \mathrm{~h}$ after exposure to gas plasma or argon gas. Data show boxplots from 6-8 patients, and statistical analysis was performed using $t$-test with $p<0.05\left(^{*}\right)$ and $p<0.01\left(^{* *}\right)$. 
SCC chemokines, cytokines, growth factors $(\mathrm{pg} / \mathrm{ml})$
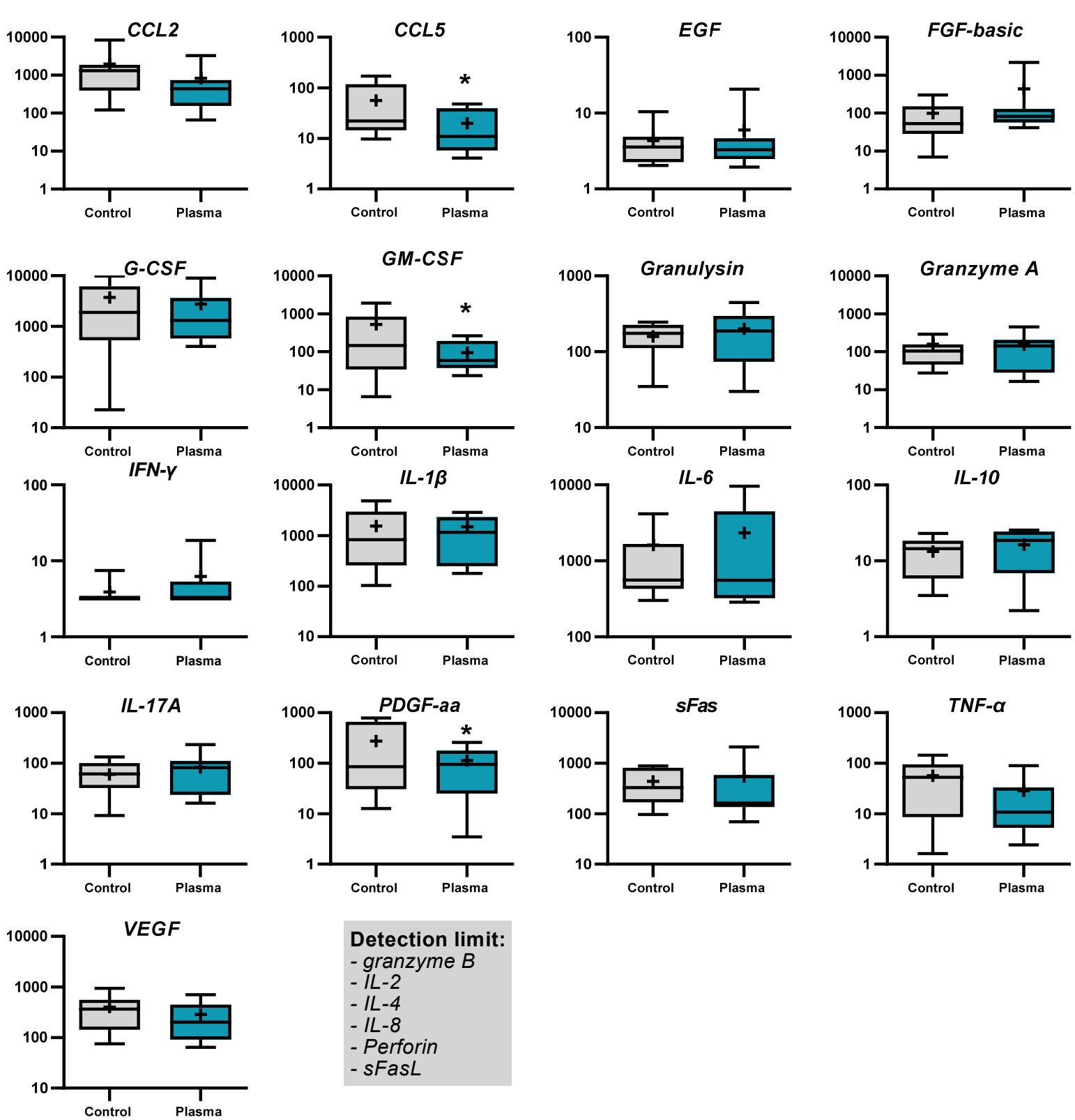

Figure 5. Secretion profile of SCCs: quantification of chemokines, cytokines, and growth factors in $\mathrm{pg} / \mathrm{mL}$ in BCC tissue culture supernatants $24 \mathrm{~h}$ after exposure to gas plasma or argon gas. Data show boxplots from 6-8 patients, and statistical analysis was performed using $t$-test with $p<0.05\left(^{*}\right)$.

\section{Discussion}

The capacity of cold physical plasma employed in medical gas plasma technology in killing tumor cells was predicted via the direct induction of ROS in tumor cells and the inhibition of tumor cells' defense mechanism and antioxidant mechanisms [35,36]. This study demonstrated gas plasma-induced toxicity in vitro and in patient-derived skin cancer samples ex vivo together with immunomodulatory effects.

In vitro, a gas plasma exposure time-dependent and selective toxicity was observed. In general, the selectivity of gas plasma treatment is a matter of debate and depends on the type of cell line used as comparator [9]. Hence, both selectivity [37,38] and nonselectivity $[39,40]$ have been observed. Our findings of cell cycle arrest underline previous findings as well [41,42]. H2AX phosphorylation following gas plasma treatment has 
also been described before [43,44], albeit it should be noted that $\gamma \mathrm{H} 2 \mathrm{AX}$ induction is a consequence of apoptosis rather than directly short-lived ROS-mediated DNA doublestrand breaks [45]. Pro-apoptotic effects of gas plasma in three-dimensional tumor tissues have been observed several times using, for instance, in vivo tumors [46,47] and tumor animal models $[48,49]$. However, regarding patient-derived skin tumor biopsies, we here describe gas plasma-induced apoptosis in cutaneous SCC and BCC. For oral SCC, gas plasma-induced apoptosis using the kINPen plasma jet has been reported before [50].

Gas plasma treatment of skin cancer tissues changed the expression and release of immuno-related molecules, respectively. CD86 is readily expressed by professional antigen-expressing cells to support $\mathrm{T}$ cell activation and was found to be decreased in gas plasma-treated SCC and BCC tissue samples. However, CD86 also is readily expressed on tumor cells [51-53], for reasons which to date remain unknown. High CD86 has been linked to unfavorable prognosis in different types of tumors [54,55]. CD206 remained unchanged in our study. The molecule is a M2a macrophage polarization marker (also called tumor-associated macrophage (TAM)) [56] and is associated with disease severity in BCC [57]. FOXP3-expressing $\mathrm{T}_{\text {regs }}$ are also a poor prognostic marker in BCC as well as SCC $[58,59]$. Although realistic immunodynamics, including extravasation and the infiltration of new leukocytes, is not reflected in our ex vivo model, our data at least suggest that gas plasma treatment also has an immunological dimension. The findings in tissuecultured supernatants underlined this. The changes in BCC samples were more pronounced compared to SCC after gas plasma treatment. Both had a marked downregulation of CCL5 (RANTES) in common. There are many sources of CCL5 in skin cancer, for instance, dendritic cells, macrophages, cancer-associated fibroblasts, keratinocytes, mast cells, and tumor cells [60-62]. CCL5 serves as chemoattractant for lymphocytes and promotes tumorsupportive $\mathrm{T}_{\mathrm{H}} 2$ polarization [63]. The molecule is associated with poor prognosis in many types of cancers [64-66]. In BCC, but not SCC samples, gas plasma stimulated elevated levels of IL-17A. This was probably due to the higher baseline expression of IL-17A in BCC that is associated with a favorable prognosis [67]. GM-CSF levels significantly declined in SCC and BCC following gas plasma exposure. GM-CSF has pleiotropic roles in tumor biology, and expression is elevated in SCC [68], while at the same time, it has also been used as a therapeutic agent in non-melanoma skin cancer [69].

It is widely assumed that ROS are the main drivers of gas plasma-mediated tumor cell toxicity, especially in vitro [24]. Regarding the significance of ROS for tissue-mediated effects, less evidence is available. This is because tools that are capable of detecting ROS in tissues are generally scarce. Recently, we showed for the first time the direct oxidation of plasma-derived ROS into human subcutaneous tumors grown in immunodeficient mice using a luminescent probe [70]. In a human head and neck cancer patient, changes in the microcirculation were directly observed after plasma treatment [71], pointing to a role of fast effectors such as ROS and/or electric fields. Regarding the latter, mounting evidence suggests that electric fields modulated in gas plasma sources are in contact with targets [72,73]. Final evidence and models are awaited to distinguish the role of different effectors in the gas plasma treatment of tissues. This includes the types of species dominating biological effects in tissues. While in plasma-treated liquids [74] and in vitro, depending on the feed gas admixture used, the dominant presence of a few long-lived species were described [75], the main types of ROS reaching the target tissue at sufficient depth and quantity as well as the putative secondary redox chemistry remains to be elucidated. The physics and redox chemistry of the kINPen in the plasma gas phase is, by contrast, very well explored [76].

\section{Materials and Methods}

\subsection{Cell Culture}

The human skin epidermoid squamous cell carcinoma cell line A431, the human epidermal squamous carcinoma cell line SCC-13, the human melanoma cell line A375, and the human non-malignant $\mathrm{HaCaT}$ keratinocyte cell line were grown in fully supplemented 
(10\% fetal bovine serum, 1\% penicillin/streptomycin, and $2 \%$ glutamine) Roswell Park Memorial Institute (RPMI) 1640 medium (Pan-Biotech, Aidenbach, Germany). All cell lines were passaged twice per week and maintained under standard culture conditions $\left(37^{\circ} \mathrm{C}\right.$, $5 \% \mathrm{CO}_{2}, 95 \%$ humidity). For experiments, $1 \times 10^{5}$ cells were seeded per well of a 24 -well plate (NUNC, Roskilde, Denmark) in $500 \mu \mathrm{L}$ of fully supplemented cell culture media.

\subsection{Primary Skin Tumor Material}

Study approval was received from the University of Duisburg-Essen (ethical committee of the University of Duisburg-Essen) under the Institutional Review Board protocol number 12-4961-BO. Patient samples were retrieved upon informed consent to perform the experiments and anonymously publish the data. Primary tumor material from human cutaneous squamous cell carcinoma (SCC) and basal cell carcinoma (BCC) was collected from ten patients each during surgery. Subsequently, $3 \mathrm{~mm}$ punch biopsies (without hampering histological diagnosis) were generated for each tissue in the laboratory to generate skin cancer tissue samples for further experiments with a standardized size and volume. The biopsies were added to customized conical receptacles, which were added to 96-well holders to ensure a standardized location and maintain their upright position.

\subsection{Gas Plasma Exposure}

The atmospheric pressure plasma jet kINPen (neoplas $\mathrm{GmbH}$ ) was utilized for the in vitro experiments. The ambient air conditions were not monitored as it was recently shown that its role in the kINPen plasma jet's tumor toxicity is minor [14,77]. For in vitro experiments, the argon feed gas flowed through a capillary (inner diameter $1.6 \mathrm{~mm}$ ) with 1.5 standard liters per minute and plasma was ignited by a radio frequency voltage (1.1 MHz/2-6 kV, peak to peak, non-pulsed). A motorized and computer-controlled xyztable (CNC, Germany) was used to hover the gas plasma jet over the central position of each well for different dwell times (15 s, 30 s, 45 s, 60 s, and 90 s). The exposure distance from the nozzle to the liquid target (as common in cell culture experiments) was $15 \mathrm{~mm}$. The main reactive species being generated in the kINPen plasma gas phase and treated liquids have been thoroughly described before [76,78,79]. As a control, the samples were exposed to argon gas alone. Liquid evaporation was compensated for by adding predetermined amounts of double-distilled water immediately following the treatment. For the treatment of primary human skin biopsies, the atmospheric pressure argon plasma jet kINPen MED (neoplas MED, Greifswald, Germany) was used. The jet is accredited as medical product class IIa in the European Union for dermatological applications, especially wound healing [80], but it has not yet received licensing for cancer treatment. The gas plasma was generated at a frequency of $1 \mathrm{MHz}$ and using five standard liters per minute of argon gas with an effective power of $1 \mathrm{~W}$. The samples received gas plasma or argon gas treatment for $120 \mathrm{~s}$ at a distance of $1 \mathrm{~cm}$ between the capillary and the tumor tissue, so that the jet was touching the tissue surface (conductive mode). The jet was operated at body temperature and does not cause thermal damage to treated tissues [80]. Following plasma treatment ex vivo, the tumor samples received fully supplemented cell culture medium. After $24 \mathrm{~h}$ of incubation under standard culture conditions, the supernatants were collected and stored at $-80^{\circ} \mathrm{C}$ until analysis. Then, the tissue samples were embedded in OCT, added to disposable molds, snap-frozen using liquid N2, and stored at $-80{ }^{\circ} \mathrm{C}$.

\subsection{Metabolic Activity}

Twenty hours after exposure, resazurin (7-Hydroxy-3H-phenoxazin-3-one 10-oxide) was added to the cells (final concentration: $100 \mu \mathrm{M}$ ). Metabolically active cells transformed the non-fluorescent resazurin into fluorescent resorufin. After $4 \mathrm{~h}$ of incubation in the cell culture incubator, the well plate was transferred to a multimode plate reader (F200; Tecan, Mennedorf, Switzerland), and fluorescence was determined at $\lambda_{\mathrm{ex}} 535 \mathrm{~nm}$ and $\lambda_{\mathrm{em}} 590 \mathrm{~nm}$. The data were background-subtracted using wells containing fully supplemented cell culture medium without cells and resazurin and normalized against the argon gas-treated 
control, in which the plasma of the jet has been switched off. Pilot experiments confirmed no effect of the argon gas treatment compared to untreated cells.

\subsection{Apoptosis Detection}

Twenty-four hours after exposure, CellEvent caspase 3/7 detection reagent (ThermoFisher, Bremen, Germany) was added, and the cells were cultured for another $30 \mathrm{~min}$. The dye quickly entered cells and contained a fluorescent moiety with high affinity and fluorescence once bound to DNA but only after it has been released by enzymatic activity performed by the caspases 3 and 7 . Afterwards, the plate was imaged using fluorescence microscopy (Operetta CLS; PerkinElmer, Hamburg, Germany) by the acquisition of brightfield and fluorescence $\left(\lambda_{\mathrm{ex}} 475 \mathrm{~nm}\right.$ and $\lambda_{\mathrm{em}} 525 \mathrm{~nm}$ ) images, and quantitative image analysis (Harmony 4.9 software; PerkinElmer, Germany) was performed.

\subsection{Flow Cytometry}

Twenty-four hours after exposure, cells were detached using accutase and subsequently fixed and permeabilized. For cell cycle analysis, DAPI (4',6-Diamidino-2-phenylindol) was added (final concentration: $10 \mu \mathrm{M}$ ) and incubated at $4{ }^{\circ} \mathrm{C}$ for $1 \mathrm{~h}$. After washing, cells were resuspended in FACS buffer and acquired using flow cytometry (CytoFLEX LX; BeckmanCoulter, Krefeld, Germany). Alternatively, fixed cells were stained using fluorescently labeled monoclonal antibodies targeting 8-OHdG (8-Hydroxy-2'-deoxyguanosine), 3-NT (3nitrotyrosine), and $\gamma \mathrm{H} 2 \mathrm{AX}$ (phosphorylated histone 2A family member X). After $1 \mathrm{~h}$ of incubation at $4{ }^{\circ} \mathrm{C}$, cells were washed and acquired using flow cytometry. Data analysis was performed utilizing Kaluza 2.1 software (Beckman-Coulter, Germany). The quantification of cells in the G1, S, and G2 phases of the cell cycle was done using mathematical modeling based on the Michael H. Fox algorithm [81].

\subsection{Supernatant Analysis}

To detect inflammatory mediators, multiplex analysis was performed using beadbased assay kits (BioLegend, Amsterdam, The Netherlands) to simultaneously assess several cytokines, chemokines, and growth factors according to the manufacturing company's instructions. To achieve this, the supernatant collected from the tumor tissue cultures was incubated with antibody-coated beads. After washing, the addition of streptavidin beads, and another washing step, the analytes' mean fluorescent intensity was determined using a flow cytometry device (CytoFLEX S; Beckman-Coulter, Germany) and the LegendPlex Software (BioLegend, The Netherlands). For absolute quantification, 5-log standard curves were generated for each of the targets.

\subsection{Tissue Immunofluorescence Analysis}

Tissue material was sectioned using a cryotome to retrieve $7 \mu \mathrm{m}$-thick sections placed on the microscopy slides (SuperFrost Plus Adhesion slides; ThermoFisher, Germany). The tissues were fixed using $4 \%$ paraformaldehyde for $10 \mathrm{~min}$ at room temperature. To retrieve the antigens of interest and increase permeability, the tissues were placed into sodium citrate and Triton X-100 solution for $20 \mathrm{~min}$. Washing with PBS was performed three times, each time lasting $5 \mathrm{~min}$, between different staining stages. Then, the tissues were blocked in 3\% BSA solution in PBST for $30 \mathrm{~min}$ to prevent the non-specific binding of antibodies which were added afterwards. For staining, anti-CD86 (Abcam: Ab53004), anti-CD206 (Novus: NBP1-90020), and anti-FOXP3 (Novus: NB100-39002) antibodies were used and incubated in PBST solution containing $1 \%$ BSA overnight at $4{ }^{\circ} \mathrm{C}$. After washing, appropriate Alexa Flour 647-conjugated secondary antibodies (Thermo Fisher, Germany) were added. Then, TUNEL staining was performed according to the manufacturer's instructions (Sigma-Aldrich, Taufkirchen, Germany) for frozen tissues to identify apoptotic cells. Finally, nuclei staining was performed by using DAPI. The slides were imaged using the fluorescence microscope's 20x air objective (NA $=0.4)$ (Operetta CLS). The bandpass centers for fluorescence capturing were $\lambda_{\text {ex }} 365 \mathrm{~nm}$ and $\lambda_{\mathrm{em}} 450 \mathrm{~nm}$ for detecting DAPI, 
$\lambda_{\text {ex }} 475 \mathrm{~nm}$ and $\lambda_{\text {em }} 525 \mathrm{~nm}$ for detecting TUNEL-stained apoptotic cells and $\lambda_{\mathrm{ex}} 630 \mathrm{~nm}$ and $\lambda_{\mathrm{em}} 700 \mathrm{~nm}$ for detecting the antibody-labeled cells. Image acquisition, analysis, and quantification were performed by using Harmony 4.9 software.

\subsection{Reactive Species Analysis}

To quantify the amounts of the long-lived oxidants $\mathrm{H}_{2} \mathrm{O}_{2}, \mathrm{NO}_{2}{ }^{-}$, and $\mathrm{NO}_{3}{ }^{-}$, known products of short-lived ROS/RNS generated in the plasma gas phase [34], $200 \mu \mathrm{L}$ of PBS were exposed to the kINPen as described for the treatment of cell cultures. After evaporated liquid was compensated for, analysis was performed as previously described in detail [78].

\subsection{Statistical Analysis}

Data graphing and statistical analysis were conducted using Prism 9.2 (GraphPad Software). The $T$-test was used to compare the difference between two groups statistically. The determination of $\mathrm{IC}_{25}$ values was done using nonlinear regression analysis against log2 transformed exposure times. The confidence interval was $95 \%$ for all tests, and statistically significant differences were marked with $*(p<0.05),{ }^{* *}(p<0.01)$, or ${ }^{* * *}(p<0.001)$.

\section{Conclusions}

Our proof-of-concept study shows cytotoxic and immunomodulatory effects of gas plasma jet treatment in patient-derived BCC and SCC samples, calling for future clinical exploration of this technology in non-melanoma skin cancer treatment. At the same time, substantial efforts are needed to decipher the gas plasma-derived reactive species chemistry necessary to induce the tumor toxic effects and to elucidate potential optimization routes of this technology to serve as an adjuvant oncological therapeutic option in the long term.

Author Contributions: Conceptualization, S.B.; methodology, J.M. and S.B.; software, F.S., E.F. and S.B.; formal analysis, F.S., J.B., E.F. and L.M.; investigation, F.S., J.M., J.B., E.F. and L.M.; resources, S.B.; writing—original draft preparation, S.B.; writing—review and editing, all authors; visualization, F.S., J.B. and S.B.; supervision, I.H., I.S., S.E. and S.B.; project administration, I.H., I.S., S.E. and S.B.; funding acquisition, S.B. All authors have read and agreed to the published version of the manuscript.

Funding: S.B. acknowledges funding by the German Federal Ministry of Education and Research (BMBF, grant numbers 03Z22DN11 and 03Z22Di1), the Head and Neck Cancer Foundation Germany (Stiftung Tumorforschung Kopf-Hals), and the Gerhard-Domagk Foundation (Greifswald, Germany). S.B. and S.E. acknowledge funding by the European Social Fund (ESF, grant numbers ESF/14-BMA550001/18 and ESF/14-BMA55-0006/18; ONKOTHER-H) and the Ministry of Education, Science and Culture of Mecklenburg-Vorpommern (MV). SE is supported by the: DFG (EM 68/13-1); TBI Ministry of Commerce, Occupation, and Health of MV Germany and EFRE (TBI-V-1-349-VBW-120); VDI, Ministry of Education and Research, Germany (16GW0345); PTJ, Ministry for Commerce and Energy, Germany (03TN0019B).

Institutional Review Board Statement: Study approval was received from the University of DuisburgEssen (ethical committee of the University of Duisburg-Essen) under the Institutional Review Board protocol number 12-4961-BO.

Informed Consent Statement: Patient samples were retrieved upon informed consent.

Data Availability Statement: The underlying data are available from the corresponding author upon reasonable request.

Acknowledgments: Technical support by Felix Niessner (ZIK plasmatis, INP, Germany) is gratefully acknowledged.

Conflicts of Interest: The authors report no conflict of interest. 


\section{References}

1. Didona, D.; Paolino, G.; Bottoni, U.; Cantisani, C.J.B. Non melanoma skin cancer pathogenesis overview. Biomedicines 2018, 6, 6. [CrossRef] [PubMed]

2. Schafer, M.; Semmler, M.L.; Bernhardt, T.; Fischer, T.; Kakkassery, V.; Ramer, R.; Hein, M.; Bekeschus, S.; Langer, P.; Hinz, B.; et al. Small molecules in the treatment of squamous cell carcinomas: Focus on indirubins. Cancers (Basel) 2021, 13, 1770. [CrossRef] [PubMed]

3. Apalla, Z.; Lallas, A.; Sotiriou, E.; Lazaridou, E.; Ioannides, D. Epidemiological trends in skin cancer. Derm. Pr. Concept. 2017, 7, 2. [CrossRef]

4. Georgescu, S.R.; Mitran, C.I.; Mitran, M.I.; Caruntu, C.; Caruntu, A.; Lupu, M.; Matei, C.; Constantin, C.; Neagu, M. Tumour microenvironment in skin carcinogenesis. Tumor Microenviron. Organs 2020, 1226, 123-142.

5. Ahmed, F.; Haass, N.K. Microenvironment-driven dynamic heterogeneity and phenotypic plasticity as a mechanism of melanoma therapy resistance. Front. Oncol. 2018, 8, 173. [CrossRef]

6. Muppalla, J.N.K.; MuDDaNa, K.; Dorankula, S.P.R.; Thokala, M.R.; Pasupula, A.P. Microenvironment-a role in tumour progression and prognosis. J. Clin. Diagn. Res. JCDR 2013, 7, 2096.

7. Balkwill, F.R.; Capasso, M.; Hagemann, T. The tumor microenvironment at a glance. J. Cell Sci. 2012, 125, 5591-5596. [CrossRef]

8. Ziani, L.; Chouaib, S.; Thiery, J. Alteration of the antitumor immune response by cancer-associated fibroblasts. Front. Immunol. 2018, 9, 414. [CrossRef] [PubMed]

9. Bekeschus, S.; Liebelt, G.; Menz, J.; Berner, J.; Sagwal, S.K.; Wende, K.; Weltmann, K.D.; Boeckmann, L.; von Woedtke, T.; Metelmann, H.R.; et al. Tumor cell metabolism correlates with resistance to gas plasma treatment: The evaluation of three dogmas. Free Radic. Biol. Med. 2021, 167, 12-28. [CrossRef] [PubMed]

10. Gay-Mimbrera, J.; Garcia, M.C.; Isla-Tejera, B.; Rodero-Serrano, A.; Garcia-Nieto, A.V.; Ruano, J. Clinical and biological principles of cold atmospheric plasma application in skin cancer. Adv. Ther. 2016, 33, 894-909. [CrossRef]

11. Yan, D.; Wang, Q.; Malyavko, A.; Zolotukhin, D.B.; Adhikari, M.; Sherman, J.H.; Keidar, M. The anti-glioblastoma effect of cold atmospheric plasma treatment: Physical pathway v.s. Chemical pathway. Sci. Rep. 2020, 10, 11788. [CrossRef]

12. Gjika, E.; Pal-Ghosh, S.; Kirschner, M.E.; Lin, L.; Sherman, J.H.; Stepp, M.A.; Keidar, M. Combination therapy of cold atmospheric plasma (cap) with temozolomide in the treatment of u87mg glioblastoma cells. Sci. Rep. 2020, 10, 16495. [CrossRef]

13. Saadati, F.; Mahdikia, H.; Abbaszadeh, H.A.; Abdollahifar, M.A.; Khoramgah, M.S.; Shokri, B. Comparison of direct and indirect cold atmospheric-pressure plasma methods in the b16f10 melanoma cancer cells treatment. Sci. Rep. 2018, 8, 7689. [CrossRef] [PubMed]

14. Hasse, S.; Meder, T.; Freund, E.; von Woedtke, T.; Bekeschus, S. Plasma treatment limits human melanoma spheroid growth and metastasis independent of the ambient gas composition. Cancers (Basel) 2020, 12, 2570. [CrossRef]

15. Adil, B.H.; Al-Shammari, A.M.; Murbat, H.H. Breast cancer treatment using cold atmospheric plasma generated by the fe-dbd scheme. Clin. Plas. Med. 2020, 19, 100103. [CrossRef]

16. Wang, M.; Holmes, B.; Cheng, X.; Zhu, W.; Keidar, M.; Zhang, L.G. Cold atmospheric plasma for selectively ablating metastatic breast cancer cells. PLoS ONE 2013,8, e73741. [CrossRef] [PubMed]

17. Terefinko, D.; Dzimitrowicz, A.; Bielawska-Pohl, A.; Klimczak, A.; Pohl, P.; Jamroz, P. The influence of cold atmospheric pressure plasma-treated media on the cell viability, motility, and induction of apoptosis in human non-metastatic (mcf7) and metastatic (mda-mb-231) breast cancer cell lines. Int. J. Mol. Sci. 2021, 22, 3855. [CrossRef]

18. Schneider, C.; Arndt, S.; Zimmermann, J.L.; Li, Y.; Karrer, S.; Bosserhoff, A.K. Cold atmospheric plasma treatment inhibits growth in colorectal cancer cells. Biol. Chem. 2018, 400, 111-122. [CrossRef]

19. Ishaq, M.; Evans, M.D.; Ostrikov, K.K. Atmospheric pressure gas plasma-induced colorectal cancer cell death is mediated by nox2-ask1 apoptosis pathways and oxidative stress is mitigated by srx-nrf2 anti-oxidant system. Biochim. Et Biophys. Acta (BBA)-Mol. Cell Res. 2014, 1843, 2827-2837. [CrossRef]

20. Chauvin, J.; Judee, F.; Merbahi, N.; Vicendo, P. Effects of plasma activated medium on head and neck fadu cancerous cells: Comparison of 3d and 2d response. Anticancer. Agents Med. Chem. 2018, 18, 776-783. [CrossRef]

21. Hasse, S.; Seebauer, C.; Wende, K.; Schmidt, A.; Metelmann, H.-R.; von Woedtke, T.; Bekeschus, S. Cold argon plasma as adjuvant tumour therapy on progressive head and neck cancer: A preclinical study. Appl. Sci. 2019, 9, 2061. [CrossRef]

22. Golubitskaya, E.A.; Troitskaya, O.S.; Yelak, E.V.; Gugin, P.P.; Richter, V.A.; Schweigert, I.V.; Zakrevsky, D.E.; Koval, O.A. Cold physical plasma decreases the viability of lung adenocarcinoma cells. Acta Nat. 2019, 11, 16-19. [CrossRef]

23. Kurita, H.; Haruta, N.; Uchihashi, Y.; Seto, T.; Takashima, K. Strand breaks and chemical modification of intracellular DNA induced by cold atmospheric pressure plasma irradiation. PLoS ONE 2020, 15, e0232724. [CrossRef] [PubMed]

24. Privat-Maldonado, A.; Schmidt, A.; Lin, A.; Weltmann, K.D.; Wende, K.; Bogaerts, A.; Bekeschus, S. Ros from physical plasmas: Redox chemistry for biomedical therapy. Oxid. Med. Cell. Longev. 2019, 2019, 9062098. [CrossRef] [PubMed]

25. Gorbanev, Y.; Privat-Maldonado, A.; Bogaerts, A. Analysis of short-lived reactive species in plasma-air-water systems: The dos and the do nots. Anal. Chem. 2018, 90, 13151-13158. [CrossRef]

26. Redza-Dutordoir, M.; Averill-Bates, D.A. Activation of apoptosis signalling pathways by reactive oxygen species. Biochim. Et Biophys. Acta (BBA)-Mol. Cell Res. 2016, 1863, 2977-2992. [CrossRef] [PubMed]

27. Schneider, C.; Gebhardt, L.; Arndt, S.; Karrer, S.; Zimmermann, J.L.; Fischer, M.J.M.; Bosserhoff, A.K. Cold atmospheric plasma causes a calcium influx in melanoma cells triggering cap-induced senescence. Sci. Rep. 2018, 8, 10048. [CrossRef] 
28. Huang, G.; Pan, S.-T. Ros-mediated therapeutic strategy in chemo-/radiotherapy of head and neck cancer. Oxid. Med. Cell Longev. 2020, 2020, 5047987. [CrossRef]

29. Zhou, Z.; Song, J.; Nie, L.; Chen, X. Reactive oxygen species generating systems meeting challenges of photodynamic cancer therapy. Chem. Soc. Rev. 2016, 45, 6597-6626. [CrossRef] [PubMed]

30. Weinberg, F.; Ramnath, N.; Nagrath, D. Reactive oxygen species in the tumor microenvironment: An overview. Cancers (Basel) 2019, 11, 1191. [CrossRef]

31. Gorrini, C.; Harris, I.S.; Mak, T.W. Modulation of oxidative stress as an anticancer strategy. Nat. Rev. Drug Discov. 2013, $12,931-947$. [CrossRef]

32. Chow, M.T.; Luster, A.D. Chemokines in cancer. Cancer Immunol. Res. 2014, 2, 1125-1131. [CrossRef]

33. Galluzzi, L.; Buque, A.; Kepp, O.; Zitvogel, L.; Kroemer, G. Immunogenic cell death in cancer and infectious disease. Nat. Rev. Immunol. 2017, 17, 97-111. [CrossRef]

34. Wende, K.; von Woedtke, T.; Weltmann, K.D.; Bekeschus, S. Chemistry and biochemistry of cold physical plasma derived reactive species in liquids. Biol. Chem. 2018, 400, 19-38. [CrossRef] [PubMed]

35. Sardella, E.; Veronico, V.; Gristina, R.; Grossi, L.; Cosmai, S.; Striccoli, M.; Buttiglione, M.; Fracassi, F.; Favia, P. Plasma treated water solutions in cancer treatments: The contrasting role of rns. Antioxidants (Basel) 2021, 10, 605. [CrossRef]

36. Trachootham, D.; Alexandre, J.; Huang, P. Targeting cancer cells by ros-mediated mechanisms: A radical therapeutic approach? Nat. Rev. Drug Discov. 2009, 8, 579-591. [CrossRef] [PubMed]

37. Guerrero-Preston, R.; Ogawa, T.; Uemura, M.; Shumulinsky, G.; Valle, B.L.; Pirini, F.; Ravi, R.; Sidransky, D.; Keidar, M.; Trink, B. Cold atmospheric plasma treatment selectively targets head and neck squamous cell carcinoma cells. Int. J. Mol. Med. 2014, 34, 941-946. [CrossRef] [PubMed]

38. Kim, S.J.; Joh, H.M.; Chung, T.H. Production of intracellular reactive oxygen species and change of cell viability induced by atmospheric pressure plasma in normal and cancer cells. Appl. Phys. Lett. 2013, 103, 153705. [CrossRef]

39. Bundscherer, L.; Bekeschus, S.; Tresp, H.; Hasse, S.; Reuter, S.; Weltmann, K.-D.; Lindequist, U.; Masur, K. Viability of human blood leukocytes compared with their respective cell lines after plasma treatment. Plasma Med. 2013, 3, 71-80. [CrossRef]

40. Girard, P.M.; Arbabian, A.; Fleury, M.; Bauville, G.; Puech, V.; Dutreix, M.; Sousa, J.S. Synergistic effect of h2o2 and no2 in cell death induced by cold atmospheric he plasma. Sci. Rep. 2016, 6, 29098. [CrossRef]

41. Akter, M.; Jangra, A.; Choi, S.A.; Choi, E.H.; Han, I. Non-thermal atmospheric pressure bio-compatible plasma stimulates apoptosis via p38/mapk mechanism in u87 malignant glioblastoma. Cancers (Basel) 2020, 12, 245. [CrossRef]

42. Gherardi, M.; Turrini, E.; Laurita, R.; De Gianni, E.; Ferruzzi, L.; Liguori, A.; Stancampiano, A.; Colombo, V.; Fimognari, C. Atmospheric non-equilibrium plasma promotes cell death and cell-cycle arrest in a lymphoma cell line. Plasma Process. Polym. 2015, 12, 1354-1363. [CrossRef]

43. Adhikari, M.; Kaushik, N.; Ghimire, B.; Adhikari, B.; Baboota, S.; Al-Khedhairy, A.A.; Wahab, R.; Lee, S.J.; Kaushik, N.K.; Choi, E.H. Cold atmospheric plasma and silymarin nanoemulsion synergistically inhibits human melanoma tumorigenesis via targeting hgf/c-met downstream pathway. Cell Commun. Signal. 2019, 17, 52. [CrossRef]

44. Chang, J.W.; Kang, S.U.; Shin, Y.S.; Kim, K.I.; Seo, S.J.; Yang, S.S.; Lee, J.S.; Moon, E.; Baek, S.J.; Lee, K.; et al. Non-thermal atmospheric pressure plasma induces apoptosis in oral cavity squamous cell carcinoma: Involvement of DNA-damage-triggering sub-g(1) arrest via the atm/p53 pathway. Arch. Biochem. Biophys. 2014, 545, 133-140. [CrossRef]

45. Bekeschus, S.; Schutz, C.S.; Niessner, F.; Wende, K.; Weltmann, K.D.; Gelbrich, N.; von Woedtke, T.; Schmidt, A.; Stope, M.B. Elevated h2ax phosphorylation observed with kinpen plasma treatment is not caused by ros-mediated DNA damage but is the consequence of apoptosis. Oxid. Med. Cell. Longev. 2019, 2019, 8535163. [CrossRef] [PubMed]

46. Freund, E.; Spadola, C.; Schmidt, A.; Privat-Maldonado, A.; Bogaerts, A.; von Woedtke, T.; Weltmann, K.-D.; Heidecke, C.-D.; Partecke, L.-I.; Käding, A.; et al. Risk evaluation of emt and inflammation in metastatic pancreatic cancer cells following plasma treatment. Front. Phys. 2020, 8, 569618. [CrossRef]

47. Liedtke, K.R.; Diedrich, S.; Pati, O.; Freund, E.; Flieger, R.; Heidecke, C.D.; Partecke, L.I.; Bekeschus, S. Cold physical plasma selectively elicits apoptosis in murine pancreatic cancer cells in vitro and in ovo. Anticancer. Res. 2018, 38, 5655-5663. [CrossRef] [PubMed]

48. Xiang, L.; Xu, X.; Zhang, S.; Cai, D.; Dai, X. Cold atmospheric plasma conveys selectivity on triple negative breast cancer cells both in vitro and in vivo. Free Radic. Biol. Med. 2018, 124, 205-213. [CrossRef]

49. Zhang, H.; Zhang, J.; Guo, B.; Chen, H.; Xu, D.; Kong, M.G. The antitumor effects of plasma-activated saline on muscle-invasive bladder cancer cells in vitro and in vivo demonstrate its feasibility as a potential therapeutic approach. Cancers (Basel) 2021, $13,1042$. [CrossRef] [PubMed]

50. Schuster, M.; Seebauer, C.; Rutkowski, R.; Hauschild, A.; Podmelle, F.; Metelmann, C.; Metelmann, B.; von Woedtke, T.; Hasse, S.; Weltmann, K.D.; et al. Visible tumor surface response to physical plasma and apoptotic cell kill in head and neck cancer. J. Craniomaxillofac. Surg. 2016, 44, 1445-1452. [CrossRef] [PubMed]

51. Flörcken, A.; Johannsen, M.; Nguyen-Hoai, T.; Gerhardt, A.; Miller, K.; Dörken, B.; Pezzutto, A.; Westermann, J.; Jöhrens, K. Immunomodulatory molecules in renal cell cancer: Cd80 and cd86 are expressed on tumor cells. Int. J. Clin. Exp. Pathol. 2017, 10, 1443-1454.

52. Harnack, U.; Johnen, H.; Pecher, G. Natural killer cell line yt exerts cytotoxicity against cd86+ myeloma cells. Anticancer. Res. 2011, 31, 475-479. [PubMed] 
53. Wollenberg, B.; Zeidler, R.; Lebeau, A.; Mack, B.; Lang, S. Lack of b7.1 and b7.2 on head and neck cancer cells and possible significance for gene therapy. Int. J. Mol. Med. 1998, 2, 167-171. [CrossRef] [PubMed]

54. Qiu, H.; Tian, W.; He, Y.; Li, J.; He, C.; Li, Y.; Liu, N.; Li, J. Integrated analysis reveals prognostic value and immune correlates of cd86 expression in lower grade glioma. Front. Oncol. 2021, 11, 654350. [CrossRef] [PubMed]

55. Dong, P.; Ma, L.; Liu, L.; Zhao, G.; Zhang, S.; Dong, L.; Xue, R.; Chen, S. Cd86(+)/cd206(+), diametrically polarized tumorassociated macrophages, predict hepatocellular carcinoma patient prognosis. Int. J. Mol. Sci. 2016, 17, 320. [CrossRef] [PubMed]

56. Laoui, D.; Movahedi, K.; Van Overmeire, E.; Van den Bossche, J.; Schouppe, E.; Mommer, C.; Nikolaou, A.; Morias, Y.; De Baetselier, P.; Van Ginderachter, J.A. Tumor-associated macrophages in breast cancer: Distinct subsets, distinct functions. Int. J. Dev. Biol. 2011, 55, 861-867. [CrossRef]

57. Tjiu, J.W.; Chen, J.S.; Shun, C.T.; Lin, S.J.; Liao, Y.H.; Chu, C.Y.; Tsai, T.F.; Chiu, H.C.; Dai, Y.S.; Inoue, H.; et al. Tumor-associated macrophage-induced invasion and angiogenesis of human basal cell carcinoma cells by cyclooxygenase-2 induction. J. Investig. Dermatol. 2009, 129, 1016-1025. [CrossRef]

58. Yao, Q.; Epstein, C.B.; Banskota, S.; Issner, R.; Kim, Y.; Bernstein, B.E.; Pinello, L.; Asgari, M.M. Epigenetic alterations in keratinocyte carcinoma. J. Investig. Dermatol. 2021, 141, 1207-1218. [CrossRef]

59. Kaporis, H.G.; Guttman-Yassky, E.; Lowes, M.A.; Haider, A.S.; Fuentes-Duculan, J.; Darabi, K.; Whynot-Ertelt, J.; Khatcherian, A.; Cardinale, I.; Novitskaya, I.; et al. Human basal cell carcinoma is associated with foxp3+ $\mathrm{t}$ cells in a th2 dominant microenvironment. J. Investig. Dermatol. 2007, 127, 2391-2398. [CrossRef]

60. Bridge, J.A.; Lee, J.C.; Daud, A.; Wells, J.W.; Bluestone, J.A. Cytokines, chemokines, and other biomarkers of response for checkpoint inhibitor therapy in skin cancer. Front. Med. (Lausanne) 2018, 5, 351. [CrossRef]

61. Ribatti, D.; Tamma, R.; Annese, T.; Crivellato, E. The r.role of mast cells in human skin cancers. Clin. Exp. Med. 2021, 21, 355-360. [CrossRef] [PubMed]

62. Varricchi, G.; Galdiero, M.R.; Marone, G.; Granata, F.; Borriello, F.; Marone, G. Controversial role of mast cells in skin cancers. Exp. Dermatol. 2017, 26, 11-17. [CrossRef] [PubMed]

63. Zhang, Q.; Qin, J.; Zhong, L.; Gong, L.; Zhang, B.; Zhang, Y.; Gao, W.Q. Ccl5-mediated th2 immune polarization promotes metastasis in luminal breast cancer. Cancer Res. 2015, 75, 4312-4321. [CrossRef]

64. Huang, R.; Wang, S.; Wang, N.; Zheng, Y.; Zhou, J.; Yang, B.; Wang, X.; Zhang, J.; Guo, L.; Wang, S.; et al. Ccl5 derived from tumor-associated macrophages promotes prostate cancer stem cells and metastasis via activating beta-catenin/stat 3 signaling. Cell Death Dis. 2020, 11, 234. [CrossRef]

65. Sun, K.; Gong, C.; Peng, H.; Fang, H.; Zhou, J.; Li, J.; Chen, S.; Zheng, H. High ccl5 expression is associated with osteosarcoma metastasis and poor prognosis of patients with osteosarcoma. Mol. Med. Rep. 2017, 16, 6953-6957. [CrossRef]

66. Aldinucci, D.; Colombatti, A. The inflammatory chemokine ccl5 and cancer progression. Mediat. Inflamm. 2014, $2014,292376$. [CrossRef]

67. Pellegrini, C.; Orlandi, A.; Costanza, G.; Di Stefani, A.; Piccioni, A.; Di Cesare, A.; Chiricozzi, A.; Ferlosio, A.; Peris, K.; Fargnoli, M.C. Expression of il-23/th17-related cytokines in basal cell carcinoma and in the response to medical treatments. PLoS ONE 2017, 12, e0183415. [CrossRef]

68. Lowes, M.A.; Bishop, G.A.; Cooke, B.E.; Barnetson, R.S.; Halliday, G.M. Keratoacanthomas have an immunosuppressive cytokine environment of increased il-10 and decreased gm-csf compared to squamous cell carcinomas. Br. J. Cancer 1999, 80, 1501-1505. [CrossRef]

69. Kang, A.; Zhao, D.; Yeh, J.J.; Lee, D.J. Updates on immunotherapy for the treatment of skin cancer. Curr. Dermatol. Rep. 2018, 7, 311-320. [CrossRef]

70. Kordt, M.; Trautmann, I.; Schlie, C.; Lindner, T.; Stenzel, J.; Schildt, A.; Boeckmann, L.; Bekeschus, S.; Kurth, J.; Krause, B.J.; et al. Multimodal imaging techniques to evaluate the anticancer effect of cold atmospheric pressure plasma. Cancers (Basel) 2021, 13, 2483. [CrossRef] [PubMed]

71. Rutkowski, R.; Schuster, M.; Unger, J.; Seebauer, C.; Metelmann, H.R.; Woedtke, T.V.; Weltmann, K.D.; Daeschlein, G. Hyperspectral imaging for in vivo monitoring of cold atmospheric plasma effects on microcirculation in treatment of head and neck cancer and wound healing. Clin. Plas. Med. 2017, 7, 52-57. [CrossRef]

72. Darny, T.; Pouvesle, J.M.; Puech, V.; Douat, C.; Dozias, S.; Robert, E. Analysis of conductive target influence in plasma jet experiments through helium metastable and electric field measurements. Plasma Sources Sci. T. 2017, 26, 045008. [CrossRef]

73. Stancampiano, A.; Chung, T.H.; Dozias, S.; Pouvesle, J.M.; Mir, L.M.; Robert, E. Mimicking of human body electrical characteristic for easier translation of plasma biomedical studies to clinical applications. IEEE Trans. Radiat. Plasma Med. Sci. 2020, 4, 335-342. [CrossRef]

74. Freund, E.; Bekeschus, S. Gas plasma-oxidized liquids for cancer treatment: Pre-clinical relevance, immuno-oncology, and clinical obstacles. IEEE Trans. Radiat. Plasma Med. Sci. 2020, accepted. [CrossRef]

75. Clemen, R.; Freund, E.; Mrochen, D.; Miebach, L.; Schmidt, A.; Rauch, B.H.; Lackmann, J.W.; Martens, U.; Wende, K.; Lalk, M.; et al. Gas plasma technology augments ovalbumin immunogenicity and ot-ii t cell activation conferring tumor protection in mice. Adv. Sci. (Weinh) 2021, 8, 2003395. [CrossRef] [PubMed]

76. Reuter, S.; von Woedtke, T.; Weltmann, K.D. The kinpen-a review on physics and chemistry of the atmospheric pressure plasma jet and its applications. J. Phys. D Appl. Phys. 2018, 51, 233001. [CrossRef] 
77. Winter, J.; Wende, K.; Masur, K.; Iseni, S.; Dunnbier, M.; Hammer, M.U.; Tresp, H.; Weltmann, K.D.; Reuter, S. Feed gas humidity: A vital parameter affecting a cold atmospheric-pressure plasma jet and plasma-treated human skin cells. J. Phys. D Appl. Phys. 2013, 46, 295401. [CrossRef]

78. Bekeschus, S.; Schmidt, A.; Niessner, F.; Gerling, T.; Weltmann, K.D.; Wende, K. Basic research in plasma medicine-a throughput approach from liquids to cells. J. Vis. Exp. 2017, e56331. [CrossRef]

79. Miebach, L.; Freund, E.; Horn, S.; Niessner, F.; Sagwal, S.K.; von Woedtke, T.; Emmert, S.; Weltmann, K.D.; Clemen, R.; Schmidt, A.; et al. Tumor cytotoxicity and immunogenicity of a novel v-jet neon plasma source compared to the kinpen. Sci. Rep. 2021, 11, 136. [CrossRef]

80. Bekeschus, S.; Schmidt, A.; Weltmann, K.-D.; von Woedtke, T. The plasma jet kinpen-a powerful tool for wound healing. Clin. Plas. Med. 2016, 4, 19-28. [CrossRef]

81. Fox, M.H. A model for the computer analysis of synchronous DNA distributions obtained by flow cytometry. Cytometry 1980, 1, 71-77. [CrossRef] [PubMed] 